\title{
The association of N-terminal pro-brain- type natriuretic peptide with hemodynamics and functional capacity in therapy-naive precapillary pulmonary hypertension: results from a cohort study
}

\author{
T. M. Berghaus ${ }^{1,2^{*}}$, J. Kutsch ${ }^{1}$, C. Faul ${ }^{1}$, W. von Scheidt ${ }^{1}$ and M. Schwaiblmair ${ }^{1}$
}

\begin{abstract}
Background: N-terminal pro-brain-type natriuretic peptide (NT-proBNP) is currently used as a surrogate marker for disease severity in pulmonary hypertension (PH). However, NT-proBNP tends to have a high variability and may insufficiently correlate with hemodynamics and exercise capacity.

Methods: To investigate the association of NT-proBNP with hemodynamics and cardio-pulmonary exercise testing (CPET) in 84 therapy-naive patients with precapillary PH.

Results: NT-proBNP levels were significantly correlated with hemodynamics and CPET parameters except for cardiac index, diffusion capacity, $\mathrm{PaO}_{2}$ at peak exercise, and peak minute ventilation. NT-proBNP correlated best with hemodynamics and CPET in women and patients $>65$ years. NT-proBNP correlated better with CPET in pulmonary arterial hypertension compared to chronic thromboembolic PH (CTEPH).
\end{abstract}

Conclusion: NT-proBNP is associated with disease severity in precapillary PH. The association might be age- and genderdependent. NT-proBNP may insufficiently correlate with disease severity in CTEPH, possibly due to comorbidity.

Keywords: N-terminal pro-brain-type natriuretic peptide (NT-proBNP), Pulmonary arterial hypertension (PAH), Chronic thromboembolic pulmonary hypertension (CTEPH), Exercise capacity, Hemodynamics, Age, Gender

\section{Background}

Pulmonary hypertension (PH) is defined as an increase in mean pulmonary arterial pressure $(\mathrm{mPAP}) \geq 25 \mathrm{mmHg}$ at rest. In the presence of a pulmonary capillary wedge pressure $(\mathrm{PCWP}) \leq 15 \mathrm{mmHg}, \mathrm{PH}$ is hemodynamically classified to be precapillary. Precapillary PH results from different clinical conditions, such as pulmonary arterial hypertension $(\mathrm{PAH}), \mathrm{PH}$ due to lung diseases, chronic thromboembolic $\mathrm{PH}(\mathrm{CTEPH})$, and $\mathrm{PH}$ with unclear and/or multifactorial mechanisms [1].

Pressure overload of the right heart due to $\mathrm{PH}$ activates the natriuretic peptide system. Brain-type natriuretic

\footnotetext{
* Correspondence: thomas.berghaus@klinikum-augsburg.de ${ }^{1}$ Department of Cardiology, Respiratory Medicine and Intensive Care, Klinikum Augsburg, Ludwig-Maximilians-University, Munich, Germany ${ }^{2}$ Klinikum Augsburg, Stenglinstrasse 2, 86156 Augsburg, Germany
}

peptide (BNP) is released in response to myocardial stretch from cardiomyocytes, where it has been synthesized as an inactive precursor (proBNP) and split into the active hormone BNP and the inactive $\mathrm{N}$-terminal fragment (NT-proBNP) [2]. While BNP has a short half-life, NT-proBNP is not further metabolized and is eliminated only by renal excretion, resulting in a longer half-life. Therefore, NT-proBNP is preferably used in clinical routine as an indicator of myocardial dysfunction.

In PAH, serum NT-proBNP levels correlate with right heart dysfunction and provide prognostic information at the time of diagnosis and during follow-up assessments $[3,4]$. However, NT-proBNP tends to have a high variability and should only be interpreted in the clinical context, as NT-proBNP may insufficiently correlate with hemodynamics and exercise capacity [1]. 
We therefore investigated the association of serum NT-proBNP with hemodynamics and functional capacity in therapy-naïve patients with precapillary $\mathrm{PH}$.

\section{Methods}

\section{Study design and patient population}

Between August 2009 and March 2016, 84 patients with precapillary $\mathrm{PH}$ could be enrolled in the study. $\mathrm{PH}$ was therapy-naive in all study participants. Patients with serum creatinine levels $>1.3 \mathrm{mg} / \mathrm{dL}$ and/or estimated glomerular filtration rates $<50 \mathrm{~mL} / \mathrm{min} / 1.73 \mathrm{~m}^{2}$ or signs of acute right heart decompensation were excluded from the trial. Relevant left heart disease was ruled out by echocardiography in every patient included in the study. All laboratory tests, cardiopulmonary exercise testing (CPET), six minute walking testing (6MWT), and right heart catheterization (RHC) were performed standardised within three consecutive workdays. The study was conducted with the approval of the local Ethics Committee. Data analysis was performed retrospectively.

\section{Lung function tests}

Pulmonary function tests included spirometry, body plethysmography, and measurement of diffusing capacity using the single-breath method (Master Screen Body and MS-PFT, Jaeger, Cardinal Health, USA). The following parameters were determined: forced vital capacity, total lung capacity, forced expiratory volume in one second, and diffusing capacity for carbon monoxide (DLCO). Blood gas analysis (ABL 725, Radiometer, Copenhagen, Denmark) was performed in arterialized capillary blood from the ear lobe without supplemental oxygen $\left(\mathrm{O}_{2}\right)$.

\section{CPET}

CPET was performed using a standardized protocol [5]. The work rate was continuously increased by 515 watts/min to a maximum tolerated level on an electromagnetically braked cycle ergometer (ViaSprint 150 p, Ergoline, Germany). Patients were encouraged to exercise until symptoms were intolerable. Blood gas analysis was done at rest and during peak exercise. The heart rate was monitored continuously and non-invasive blood pressure was taken every $2 \mathrm{~min}$. The maximum work rate was recorded. $\mathrm{O}_{2}$ uptake $\left(\mathrm{VO}_{2}\right)$, minute ventilation $(\mathrm{Ve})$ and $\mathrm{CO}_{2}$ output $\left(\mathrm{VCO}_{2}\right)$ were measured breath by breath using an adult facemask (Vmax spectra 229 D, Sensor Medics, USA). $\quad \mathrm{O}_{2}$ pulse, alveolar-arterial $\mathrm{O}_{2}$ difference $\left(\mathrm{AaDO}_{2}\right)$, and functional dead space ventilation $(\mathrm{Vd} /$ $\mathrm{Vt}$ ) were calculated as described before [5]. The anaerobic threshold (AT) was chosen at the peak $\mathrm{VO}_{2}$ at which the ventilatory equivalent for $\mathrm{O}_{2}\left(\mathrm{Ve} / \mathrm{VO}_{2}\right)$ increased, while the ventilatory equivalent for $\mathrm{CO}_{2}$
$\left(\mathrm{Ve} / \mathrm{VCO}_{2}\right)$ decreased or remained constant. Peak $\mathrm{VO}_{2}$ was defined as the value of averaged data during the final $15 \mathrm{~s}$ of exercise. The $\mathrm{Ve} / \mathrm{VCO}_{2}$ slope was determined as the linear regression slope of $\mathrm{Ve}$ and $\mathrm{VCO}_{2}$ from the start of exercise until the respiratory compensation point (the point in time at which ventilation is stimulated by acidaemia and the end-tidal $\mathrm{CO}_{2}$ begins to decrease).

\section{RHC}

RHC was performed in all patients in order to confirm precapillary $\mathrm{PH}$. A thermodilution catheter $(7.5 \mathrm{~F}$ quadruple-lumen, balloon-tipped, flow-directed, "S" Tip Swan-Ganz Catheter, Edwards Lifesciences, Irvine, USA) was inserted via the right or left femoral vein. Hemodynamic measurements were performed in supine position and included heart rate, PCWP, PAP, and right atrium pressure (RAP). $\mathrm{O}_{2}$ saturation was measured in mixed venous blood samples (ABL 725, Radiometer, Copenhagen, Denmark). The cardiac output was measured by thermodilution with $10 \mathrm{ml}$ of sterile, ice-cold isotonic $(0.9 \%)$ saline, which was injected through the right atrial lumen of the catheter; the drop in temperature at the distal thermistor was then recorded. The injectate temperature was determined by a thermistor, which was placed directly behind the right atrial inlet of the catheter. Cardiac output was calculated using a computer system (Com-2, Cardiac Output Computer, Edwards Lifesciences, Irvine, USA). In each patient, a minimum of three measurements was performed; the mean value was calculated if the variability of values was less than $10 \%$. The pulmonary vascular resistance (PVR) was calculated using a standard formula $[\mathrm{PVR}=($ mean PAP - PCWP) / cardiac output].

\section{NT-proBNP}

Serum NT-proBNP levels were measured using a one-step sandwich chemiluminescent immunoassay (Dimension Vista $^{\mathrm{Tm}}$ System, Siemens Healthcare Diagnostics Inc., Newark, USA). Blood samples were taken at rest shortly before performing CPET. Values $>125 \mathrm{pg} / \mathrm{ml}$ were considered elevated for patients younger than 75 years and $>450 \mathrm{pg} / \mathrm{ml}$ for those older than 75 years [6]. In order to avoid an underestimation or overestimation of absolute values, measured NT-proBNP levels were divided by the age-adjusted normal upper range to calculate the normalized NT-proBNP ratio. Consequently, elevated levels result in a normalized NT-proBNP ratio $>1$.

\section{Statistics}

Statistical analysis was performed using IBM SPSS Statistics Version 23.0. Continuous variables characterized by a normal distribution are shown as means \pm standard error of mean (SEM). Variables without such a 
distribution are expressed as medians with range. The Shapiro-Wilk test was used to check the normality of distribution. Nominal parameters were expressed as counts with percentage of total. Correlation analysis was performed using the Spearman correlation index. All results were tested for two-sided significance. $P$-values $<0.05$ were considered statistically significant.

\section{Results}

\section{Patients' characteristics}

The characteristics of the study population are summarized in Table 1. 84 patients could be included in the trial (46 women, 38 men, mean age 70.6 years). In all subjects, precapillary pulmonary hypertension was diagnosed with a mean PAP of $41.0 \mathrm{mmHg}$ and a median PVR of 7.4 Wood units. PAH was diagnosed in 75 patients, 12 study participants suffered from CTEPH. The median NT-proBNP level was $1500 \mathrm{pg} / \mathrm{ml}$ with a median NT-proBNP ratio of 7.53.

The mean 6MWT distance was $305 \mathrm{~m}$; the median work capacity 47 watts. The mean DLCO was measured to be $52.9 \%$ of predicted, the mean $\mathrm{AaDO}_{2}$ was $49.0 \mathrm{mmHg}$. Mean $\mathrm{VO}_{2}$ was determined to be $13.0 \mathrm{ml} /$ $\mathrm{min} / \mathrm{kg}$ with a median $\mathrm{O}_{2}$ pulse at peak exercise of $8.3 \mathrm{ml} / \mathrm{min} /$ beat. Mean $\mathrm{Vd} / \mathrm{Vt}$ was $37.1 \%$. The mean $\mathrm{Ve} /$ $\mathrm{VO}_{2}$ ratio was calculated to be 40.5 with a mean $\mathrm{Ve} /$ $\mathrm{VCO}_{2}$ slope of 44.2. The mean haemoglobin concentration was $14.3 \pm 1.2 \mathrm{mg} / \mathrm{dl}$ with no significant differences in individual subgroups studied.

\section{Correlation of NT-proBNP with hemodynamics and func- tional capacity}

In the total study population, NT-proBNP levels were significantly correlated with all parameters except CI, DLCO, $\mathrm{PaO}_{2}$ at peak exercise, and Ve (Table 2). Correlations were strongest for mPAP, PVR, $\mathrm{SvO}_{2}, 6 \mathrm{MWT}$ distance, number of breaks, work capacity, $\mathrm{VO}_{2}, \mathrm{O}_{2}$ pulse, $\mathrm{Ve} / \mathrm{VCO}_{2}, \mathrm{AaDO}_{2}$, and $\mathrm{Ve} / \mathrm{VCO}_{2}$ slope. When adjusted for gender, correlations were more or less equal for hemodynamics and 6MWT parameters in men and women. However, correlations were stronger in females for CPET parameters, especially for work capacity and $\mathrm{O}_{2}$ pulse at peak exercise. When adjusted for age, NTproBNP levels were much better correlated with hemodynamics and functional capacity in older patients than in subjects $\leq 65$ years. NT-proBNP concentrations were more strongly correlated with exercise capacity in PAH compared to CTEPH. No relevant differences were found when NT-proBNP ratios were used instead of NT-proBNP levels (data not shown); thus, only correlations with NT-proBNP values are displayed, as they are much more established in the routine risk stratification of $\mathrm{PH}$ patients.
Table 1 Patients characteristics $(n=84)$

\begin{tabular}{|c|c|}
\hline \multicolumn{2}{|l|}{ Clinical profile } \\
\hline Female / male [n (\%)] & $46(54.8) / 38(45.2$ \\
\hline Age (years) & $70.6 \pm 1.41$ \\
\hline BMI $\left(\mathrm{kg} / \mathrm{m}^{2}\right)$ & $27.1 \pm 0.60$ \\
\hline PHgroup 1 / 3 / 4 / 5 [n (\%)] & $\begin{array}{l}63(75) / 7(8.3) / 1 \\
(14.3) / 2(2.4)\end{array}$ \\
\hline \multicolumn{2}{|l|}{ NT-proBNP } \\
\hline NT-proBNP level (pg/ml) & $1500(38-13,538)$ \\
\hline NT-proBNP ratio & $7.53(0.09-60.60)$ \\
\hline \multicolumn{2}{|l|}{ 6-min walking test } \\
\hline Distance (m) & $305 \pm 14.3$ \\
\hline$\%$ of norm & $62.3 \pm 2.72$ \\
\hline Breaks (n) & $0(0-6)$ \\
\hline Borg scale points $(1-10)$ & $4.10 \pm 0.29$ \\
\hline \multicolumn{2}{|l|}{ Right heart catheterization } \\
\hline Mean PAP (mmHg) & $41.0 \pm 1.22$ \\
\hline Cardiac output (1/min) & $4.39 \pm 0.14$ \\
\hline Cardiac index $\left(1 / \mathrm{min} / \mathrm{m}^{2}\right)$ & $2.43 \pm 0.10$ \\
\hline PVR (Wood units) & $7.40(3.00-18.2)$ \\
\hline Mean RAP (mmHg) & $6.0(1-20)$ \\
\hline $\mathrm{SvO}_{2}(\%)$ & $61.4 \pm 0.93$ \\
\hline \multicolumn{2}{|l|}{ Lung function } \\
\hline DLCO (\%) & $52.9 \pm 2.59$ \\
\hline $\mathrm{PaO}_{2}$ at rest $(\mathrm{mmHg})$ & $56.8 \pm 1.57$ \\
\hline $\mathrm{PaO}_{2}$ at peak exercise $(\mathrm{mmHg})$ & $57.4 \pm 1.84$ \\
\hline \multicolumn{2}{|l|}{ Cardiopulmonary exercise testing } \\
\hline Work capacity (watts) & $47.0(25-150)$ \\
\hline $\mathrm{VO}_{2}(\mathrm{ml} / \mathrm{min})$ & $953 \pm 37.5$ \\
\hline $\mathrm{VO}_{2} / \mathrm{kg}$ & $13.0 \pm 0.45$ \\
\hline AT $(\mathrm{ml} / \mathrm{min} / \mathrm{kg})$ & $9.64 \pm 0.40$ \\
\hline $\begin{array}{l}\mathrm{O}_{2} \text { pulse at peak exercise } \\
\text { (ml/min/beat) }\end{array}$ & $8.30(3.50-16.0)$ \\
\hline Ve $(\mathrm{L} / \mathrm{min})$ & $52.1 \pm 2.11$ \\
\hline $\mathrm{Ve} / \mathrm{NO}_{2}$ & $40.5 \pm 1.37$ \\
\hline $\mathrm{Ve} / \mathrm{NCO}_{2}$ & $47.2 \pm 1.58$ \\
\hline $\mathrm{AaDO}_{2}(\mathrm{mmHg})$ & $49.0 \pm 1.76$ \\
\hline $\mathrm{Vd} / \mathrm{Vt}(\%)$ & $37.1 \pm 1.50$ \\
\hline Ve $\mathrm{NCO}_{2}$ slope & $44.2 \pm 2.06$ \\
\hline
\end{tabular}

If not stated otherwise, data is presented as mean \pm SEM or as median (range) $B M I$ : body mass index, NT-proBNP ratio: NT-proBNP level divided by the age-adjusted normal upper range, $P A P$ : pulmonary arterial pressure, $P V R$ : pulmonary vascular resistance, $R A P$ : right atrial pressure, $\mathrm{SvO}_{2}$ : mixed venous oxygen saturation, $\mathrm{DLCO}$ : lung diffusing capacity for carbon monoxide, $\mathrm{PaO}_{2}$ arterial oxygen pressure, $V_{2}$ : peak oxygen uptake, $A T$ : anaerobic threshold, Ve: peak minute ventilation, $\mathrm{Ve}_{\mathrm{VO}}$ : oxygen equivalent at anaerobic threshold, $\mathrm{Ve}$ $\mathrm{VCO}_{2}$ : carbon dioxide equivalent at anaerobic threshold, $\mathrm{AaDO}_{2}$ : alveolararterial oxygen difference at peak exercise, $V d / V t$ : functional dead space ventilation at peak exercise, $\mathrm{Ve} / \mathrm{VCO}_{2}$ slope: slope of minute ventilation to carbon dioxide output 
Table 2 Correlation of NT-proBNP with hemodynamics and functional capacity according to gender, age and PH class

\begin{tabular}{|c|c|c|c|c|c|c|c|}
\hline & & Gender & & Age & & $\mathrm{PH}$ group & \\
\hline & Total & male & female & $\leq 65$ & $>65$ & $\overline{\mathrm{PAH}}$ & CTEPH \\
\hline & $\mathrm{n}=84$ & $n=38$ & $n=46$ & $n=24$ & $n=60$ & $n=63$ & $n=12$ \\
\hline & $r$ & $r$ & $r$ & $r$ & $r$ & $r$ & $r$ \\
\hline 6MWT & & & & & & & \\
\hline Distance $(\mathrm{m})$ & $-0.430^{* * *}$ & $-0.435^{* *}$ & $-0.395^{* *}$ & -0.246 & $-0.403^{* *}$ & $-0.507^{* * *}$ & -0.175 \\
\hline$\%$ of norm & $-0.448^{* * *}$ & $-0.476^{* *}$ & $-0.467^{* *}$ & -0.295 & $-0.486^{* * *}$ & $-0.556^{* * *}$ & 0.091 \\
\hline Breaks (n) & $-0.497^{* * *}$ & $0.513^{* *}$ & $0.468^{* *}$ & 0.173 & $0.507^{* * *}$ & $0.556^{* * *}$ & 0.063 \\
\hline Borg scale & $0.299^{* *}$ & 0.283 & $0.340^{*}$ & 0.042 & $0.328^{* *}$ & $0.271^{*}$ & 0.573 \\
\hline $\mathrm{RHC}$ & & & & & & & \\
\hline mPAP $(\mathrm{mmHg})$ & $0.386^{* * *}$ & $0.454^{* *}$ & $0.318^{*}$ & 0.046 & $0.581^{* * *}$ & $0.341^{* *}$ & $0.900^{* * *}$ \\
\hline $\mathrm{CO}(1 / \mathrm{min})$ & $-0.342^{* *}$ & $-0.338^{*}$ & $-0.335^{*}$ & $-0.495^{*}$ & $-0.282^{*}$ & $-0,322^{*}$ & $-0.625^{*}$ \\
\hline $\mathrm{Cl}\left(\mathrm{l} / \mathrm{min} / \mathrm{m}^{2}\right)$ & -0.252 & -0.183 & -0.251 & -0.261 & -0.255 & $-0,384^{*}$ & -0.100 \\
\hline PVR (Wood units) & $0.460^{* * *}$ & $0.543^{* *}$ & $0.458^{* *}$ & 0.327 & $0.598^{* * *}$ & $0.488^{* * *}$ & $0.918^{* * *}$ \\
\hline mRAP $(\mathrm{mmHg})$ & $0.243^{*}$ & 0.255 & 0.231 & 0.045 & 0.270 & 0.215 & 0.260 \\
\hline $\mathrm{SVO}_{2}(\%)$ & $-0.527^{* * *}$ & $-0.572^{* * *}$ & $-0.491^{* *}$ & 0.127 & $-0.544^{* * *}$ & $-0.530^{* * *}$ & -0.528 \\
\hline Lung function & & & & & & & \\
\hline DLCO (\%) & -0.251 & -0.190 & $-0.385^{*}$ & -0.044 & -0.227 & $-0.332^{*}$ & -0.200 \\
\hline $\mathrm{PaO}_{2}$ rest $(\mathrm{mmHg})$ & $-0.250^{*}$ & -0.240 & $-0.307^{*}$ & -0.087 & -0.237 & $-0.312^{*}$ & 0.284 \\
\hline $\begin{array}{l}\mathrm{PaO}_{2} \text { exercise } \\
(\mathrm{mmHg})\end{array}$ & -0.166 & -0.056 & -0.233 & -0.109 & -0.142 & -0.221 & 0.186 \\
\hline CPET & & & & & & & \\
\hline Work (watts) & $-0.424^{* * *}$ & -0.280 & $-0.533^{* * *}$ & -0.364 & $-0.401^{* *}$ & $-0.438^{* * *}$ & -0.173 \\
\hline $\mathrm{VO}_{2}(\mathrm{ml} / \mathrm{min})$ & $-0.430^{* * *}$ & $-0.479 * *$ & $-0.375^{*}$ & -0.417 & $-0.420^{* *}$ & $-0.492^{* * *}$ & -0.035 \\
\hline $\mathrm{VO}_{2} / \mathrm{kg}$ & $-0.434^{* * *}$ & $-0.471^{* *}$ & $-0.375^{*}$ & -0.220 & $-0.462^{* * *}$ & $-0.514^{* * *}$ & -0.100 \\
\hline AT $(\mathrm{ml} / \mathrm{min} / \mathrm{kg})$ & $-0.294^{*}$ & $-0.379^{*}$ & -0.172 & -0.319 & $-0.302^{*}$ & -0.307 & $-0.618^{*}$ \\
\hline $\begin{array}{l}\mathrm{O}_{2} \text { pulse } \\
\text { (ml/min/beat) }\end{array}$ & $-0.409^{* * *}$ & $-0.329^{*}$ & $-0.497^{* * *}$ & -0.329 & $-0.459^{* * *}$ & $-0.373^{* *}$ & $-0.615^{*}$ \\
\hline Ve (L/min) & 0.007 & -0.021 & 0.001 & -0.081 & 0.079 & -0.024 & 0.119 \\
\hline $\mathrm{Ve} / \mathrm{NO}_{2}$ & $0.384^{* *}$ & 0.336 & $0.392^{*}$ & $0.791^{* * *}$ & $0.280^{*}$ & $0.479^{* * *}$ & -0.091 \\
\hline $\mathrm{Ve} / \mathrm{NCO}_{2}$ & $0.451^{* * *}$ & $0.351^{*}$ & $0.484^{* *}$ & $0.591^{*}$ & $0.386^{* *}$ & $0.465^{* *}$ & 0.519 \\
\hline $\mathrm{AaDO}_{2}(\mathrm{mmHg})$ & $0.398^{* * *}$ & $0.354^{*}$ & $0.437^{* *}$ & 0.373 & $0.394^{* *}$ & $0.452^{* * *}$ & 0.221 \\
\hline $\mathrm{Vd} / \mathrm{Nt}(\%)$ & $0.351^{* *}$ & 0.266 & $0.463^{* *}$ & 0.274 & $0.352^{* *}$ & $0.349^{* *}$ & 0.460 \\
\hline $\mathrm{Ve} / \mathrm{NCO}_{2}$ slope & $0.427^{* * *}$ & $0.445^{* *}$ & $0.433^{* *}$ & $0.470^{*}$ & $0.441^{* * *}$ & $0.471^{* * *}$ & $0.671^{*}$ \\
\hline
\end{tabular}

Level of significance: * $p<0.05 ;{ }^{* *} p<0.01 ;{ }^{* * *} p<0.001$

$\mathrm{PH}$ : pulmonary hypertension, IPAH: idiopathic pulmonary arterial hypertension, CTEPH: chronic thromboembolic pulmonary hypertension, $6 M W T$ : 6 min walking test, $R H C$ : right heart catheterisation, $P A P$ : pulmonary arterial pressure,

PVR: pulmonary vascular resistance, $\mathrm{RAP}$ : right atrial pressure, $\mathrm{SVO}_{2}$ : mixed venous oxygen saturation, DLCO: lung diffusing capacity for carbon monoxide, $\mathrm{PaO}_{2}$ : arterial oxygen pressure, $\mathrm{VO}_{2}$ : peak oxygen uptake, $A T$ : anaerobic threshold, Ve: peak minute ventilation, Ve/VO $\mathrm{O}_{2}$ : oxygen equivalent at anaerobic threshold, $\mathrm{Ve} / \mathrm{VCO}_{2}$ : carbon dioxide equivalent at anaerobic threshold, $\mathrm{AaDO}_{2}$ : alveolar-arterial oxygen difference at peak exercise, $\mathrm{Vd} / \mathrm{Vt}$ : functional dead space ventilation at peak exercise, $\mathrm{Ve} / \mathrm{VCO}_{2}$ slope: slope of minute ventilation to carbon dioxide output

\section{Discussion}

Our study was conducted in order to investigate the association of serum NT-proBNP with hemodynamics and exercise capacity in therapy-naive patients with precapillary PH. NT-proBNP levels were significantly correlated with most analysed parameters. So far, our trial confirms the results of previous studies [7]. However, remarkable differences were found when correlations were adjusted for gender, age and $\mathrm{PH}$ class.

Gender differences in NT-proBNP levels have been described before in healthy subjects $[8,9]$ and in patients suffering from left heart disease [10]. In these studies, women show higher plasma concentrations of NTproBNP $[8,10]$ and exhibit a greater increase with age compared to men [9]. To the best of our knowledge, no 
such differences have been reported in precapillary $\mathrm{PH}$ so far. In our trial, NT-proBNP levels were better correlated with CPET parameters in females compared to males. In general, exercise capacity is gender dependent [11], probably reflecting differences in muscle mass [12] or myocardial geometries and functions [13]. Recently, a study by Swift and colleagues [14] demonstrated that male PAH patients have proportionally worse right heart function despite a similar afterload compared to females. Thus, gender differences in the adaptive right ventricular remodelling in response to an impaired lung perfusion in precapillary $\mathrm{PH}$ might partly explain the different association of NT-proBNP and functional capacity in women and men in our trial.

Serum NT-proBNP concentrations increase with age in a general population, probably reflecting age-related changes in ventricular compliance, myocardial mass, or peptide clearance [8]. In contrast, functional capacity declines with age $[11,15]$. Nevertheless, in our study, serum NT-proBNP levels were much better correlated with hemodynamics and functional capacity in older patients than in subjects $\leq 65$ years, possibly reflecting a better cardio-pulmonary reserve in younger $\mathrm{PH}$ patients. Figure 1, for example, illustrates the relation between serum NT-proBNP levels and the PVR in different age groups. Whereas older study participants show a linear correlation between the biomarker and the PVR, serum levels of NT-proBNP were much lower in younger patients, even when very high PVR values could be measured. In general, right heart function declines with age [16]. In addition, a progressive increase in systolic PAP can be observed with advancing age even in healthy subjects [17], probably as a result of an age-associated blood vessel stiffening in the lungs. Consequently, increased afterload due to an impaired lung perfusion in precapillary $\mathrm{PH}$ might cause less right ventricular strain in younger individuals, possibly explaining the inferior association of serum NT-proBNP levels with disease severity in younger $\mathrm{PH}$ patients.

In our trial, NT-proBNP concentrations were much stronger correlated with exercise capacity in $\mathrm{PAH}$ compared to CTEPH. NT-proBNP indicates right ventricular pressure overload due to impaired lung perfusion in precapillary PH. For ventilation-derived CPET parameters, an impaired ventilation/perfusion matching in CTEPH compared to PAH might explain the weaker correlation with NT-proBNP in CTEPH. Ventilation/perfusion mismatching results from a more uneven lung perfusion in CTEPH, possibly due to additional thrombus formation and a more proximal vascular occlusion [18]. In contrast, PAH represents a vasculopathy that bilaterally involves distal, medium to small size arteries [19], resulting in a more balanced ventilation/perfusion match. As a consequence, ventilation-derived CPET parameters and serum NTproBNP values might be more closely associated in $\mathrm{PAH}$ compared to CTEPH. However, these observations have to be interpreted with precaution. In our rather small CTEPH cohort consisting of only 12 patients, concomitant diseases, which might limit exercise capacity independently from $\mathrm{PH}$, might be more prevalent than in the PAH cohort. Therefore, comorbidity might have biased our results and might yield a poorer association of NT-proBNP values with functional capacity in CTEPH patients.

We admit that our study has limitations. First, the average age of our study cohort was quite old, possibly resulting from a small proportion of "typical" idiopathic $\mathrm{PAH}$ patients enrolled in our trial. Advanced age could

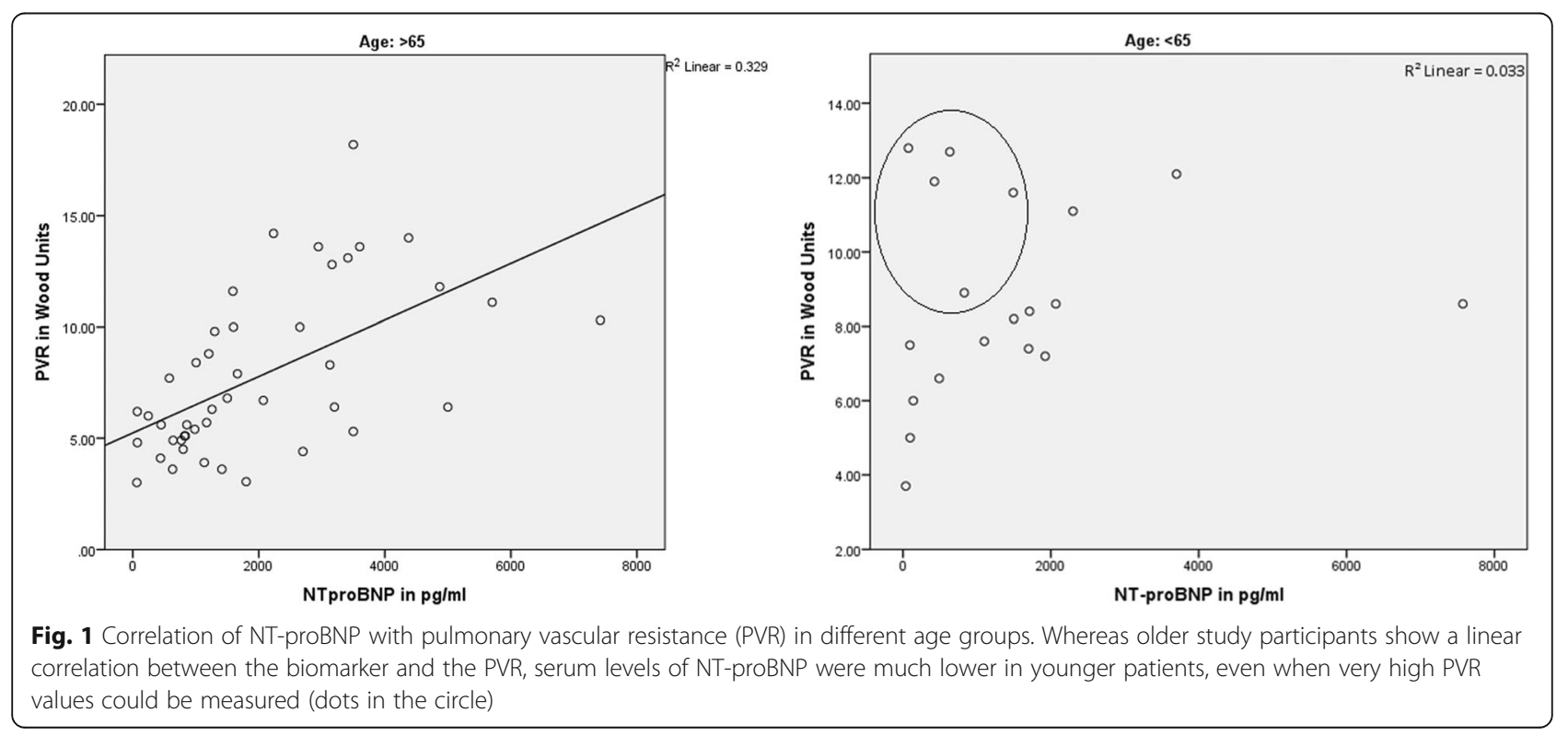


be a relevant confounder in our study. Second, only a very limited number of $\mathrm{PH}$ diagnostic group III and V patients could be enrolled. Thus, only PAH and CTEPH patients could be analyzed adequately. However, as only 12 CTEPH cases could be included in the analysis, results for this cohort are more speculative than for $\mathrm{PAH}$ patients.

\section{Conclusions}

Despite these limitations we conclude that in therapynaive patients with precapillary PH, serum NT-proBNP concentrations significantly correlate with disease severity. However, the association of the biomarker with hemodynamics and functional capacity might be ageand gender-dependent. In addition, NT-proBNP may insufficiently correlate with disease severity, especially in $\mathrm{CTEPH}$, possibly due to the influence of comorbidity.

\begin{abstract}
Abbreviations
$6 \mathrm{MWT}$ : 6 min walking test; $\mathrm{AaDO}_{2}$ : Alveolar-arterial oxygen difference at peak exercise; AT: Anaerobic threshold; CPET: Cardio-pulmonary exercise testing; CTEPH: Chronic thromboembolic pulmonary hypertension; DLCO: Lung diffusing capacity for carbon monoxide; NT-proBNP: N-terminal pro-braintype natriuretic peptide; PAH: Pulmonary arterial hypertension; $\mathrm{PaO}_{2}$ : Arterial oxygen pressure; PAP: Pulmonary arterial pressure; PCWP: Pulmonary capillary wedge pressure; PH: Pulmonary hypertension; PVR: Pulmonary vascular resistance; RAP: Right atrial pressure; RHC: Right heart catheterization; $\mathrm{SVO}_{2}$ : Mixed venous oxygen saturation; $\mathrm{Vd} / \mathrm{Nt}$ : Functional dead space ventilation at peak exercise; Ve: Peak minute ventilation; $\mathrm{Ve} / \mathrm{NCO}_{2}$ slope: Slope of minute ventilation to carbon dioxide output; Ve/ $\mathrm{VCO}_{2}$ : Carbon dioxide equivalent at anaerobic threshold; $\mathrm{Ve} / \mathrm{NO}_{2}$ : Oxygen equivalent at anaerobic threshold; $\mathrm{VO}_{2}$ : Peak oxygen uptake
\end{abstract}

\section{Acknowledgements}

The authors gratefully acknowledge the excellent assistance of Mrs. Tanja Wagner during the preparation and execution of the study.

\section{Funding}

There was no specific funding for this study.

\section{Availability of data and materials}

The datasets analysed during the current study are available from the corresponding author on reasonable request.

\section{Authors' contributions}

TMB, WvS and MS have made substantial contributions to conception and design of the study; CF and MS provided the acquisition of data; JK performed the analysis and interpretation of data; TMB and JK have been involved in drafting the manuscript; all authors have given final approval of the version to be published and agree to be accountable for all aspects of the work in ensuring that questions related to the accuracy or integrity of any part of the work are appropriately investigated and resolved. All authors read and approved the final manuscript.

\section{Ethics approval and consent to participate}

The study was conducted with the approval of the Ethics Committee at the Klinikum Augsburg (Beratungskommission für klinische Forschung (BKF), project number 201604). As data analysis was performed retrospectively, no written informed consent for study participation could be obtained.

\section{Consent for publication}

Not applicable.

\section{Competing interests}

The authors declare that they have no competing interests.

\section{Publisher's Note}

Springer Nature remains neutral with regard to jurisdictional claims in published maps and institutional affiliations.

Received: 20 January 2017 Accepted: 24 November 2017

Published online: 04 December 2017

\section{References}

1. Galiè N, Humbert M, Vachiery JL, Gibbs S, Lang I, Torbicki A, Simonneau G, Peacock A, Vonk Noordegraaf A, Beghetti M, Ghofrani A, Gomez Sanchez MA, Hansmann G, Klepetko W, Lancellotti P, Matucci M, McDonagh T, Pierard LA, Trindade PT, Zompatori M, Hoeper M, Aboyans V, Vaz Carneiro A, Achenbach S, Agewall S, Allanore Y, Asteggiano R, Paolo Badano L, Albert Barberà J, Bouvaist H, Bueno H, Byrne RA, Carerj S, Castro G, Erol Ç, Falk V, Funck-Brentano C, Gorenflo M, Granton J, lung B, Kiely DG, Kirchhof P, Kjellstrom B, Landmesser U, Lekakis J, Lionis C, Lip GY, Orfanos SE, Park MH, Piepoli MF, Ponikowski P, Revel MP, Rigau D, Rosenkranz S, Völler H, Luis ZJ. 2015 ESC/ERS guidelines for the diagnosis and treatment of pulmonary hypertension: the joint task force for the diagnosis and treatment of pulmonary hypertension of the European Society of Cardiology (ESC) and the European Respiratory Society (ERS): endorsed by: Association for European Paediatric and Congenital Cardiology (AEPC), International Society for Heart and Lung Transplantation (ISHLT). Eur Heart J. 2016;37(1):67-119. doi:10.1093/eurheartj/ehv317.

2. Hall C. Essential biochemistry and physiology of (NT-pro) BNP. Eur J Heart Fail. 2004:6:257-60.

3. Souza R, Jardim C, Julio Cesar Fernandes C, Silveira Lapa M, Rabelo R, Humbert M. NT-proBNP as a tool to stratify disease severity in pulmonary arterial hypertension. Respir Med. 2007;101(1):69-75.

4. Warwick G, Thomas PS, Yates DH. Biomarkers in pulmonary hypertension. Eur Respir J. 2008;26:503-12.

5. Wasserman K, Hansen J, Sue D, et al. Principles of exercise testing and interpretation. 4rd ed. Baltimore, MD: Lippincott Williams \& Wilkens; 2004

6. Hildebrandt $\mathrm{P}$, Collinson PO. Amino-terminal pro-B-type natriuretic peptide testing to assist the diagnostic evaluation of heart failure in symptomatic primary care patients. Am J Cardiol. 2008;101:25A-8A.

7. Andreassen AK, Wergeland R, Simonsen S, Geiran O, Guevara C, Ueland T. $\mathrm{N}$-Terminal pro-B-type natriuretic peptide as an indicator of disease severity in a heterogeneous group of patients with chronic precapillary pulmonary hypertension. Am J Cardiol. 2006;98(4):525-9.

8. Raymond I, Groenning BA, Hildebrandt PR, Nilsson JC, Baumann M, Trawinski J, Pedersen F. The influence of age, sex and other variables on the plasma level of $\mathrm{N}$-terminal pro brain natriuretic peptide in a large sample of the general population. Heart. 2003;89(7):745-51.

9. Chen C, Sung KT, Shih SC, Liu CC, Kuo JY, Hou CJ, Hung CL, Yeh HI. Age, gender and load-related influences on left ventricular geometric remodeling, systolic Mid-Wall function, and NT-ProBNP in asymptomatic Asian population. PLoS One. 2016;11(6):e0156467. doi:10.1371/journal.pone. 0156467.

10. Luchner A, Hengstenberg C, Löwel H, Trawinski J, Baumann M, Riegger GA, Schunkert H, Holmer S. N-Terminal pro-brain natriuretic peptide after myocardial infarction: a marker of cardio-renal function. Hypertension. 2002;39(1):99-104

11. Koch B, Schäper C, Ittermann T, Spielhagen T, Dörr M, Völzke H, Opitz CF, Ewert R, Gläser S. Reference values for cardiopulmonary exercise testing in healthy volunteers: the SHIP study. Eur Respir J. 2009;33(2):389-97. doi:10.1183/09031936.00074208.

12. Barron AJ, Dhutia NM, Gläser S, Koch B, Ewert R, Obst A, Dörr M, Völzke H, Francis DP, Wensel R. Physiology of oxygen uptake kinetics: insights from incremental cardiopulmonary exercise testing in the study of health in Pomerania. IJC Metab Endocr. 2015;7:3-9.

13. Daimon M, Watanabe $H$, Abe $Y$, Hirata K, Hozumi T, Ishii K, Ito H, Iwakura K, Izumi C, Matsuzaki M, Minagoe S, Abe H, Murata K, Nakatani S, Negishi K, Yoshida K, Tanabe K, Tanaka N, Tokai K, Yoshikawa J. Japanese normal values for echocardiographic measurements project (JAMP) study investigators. Gender differences in age-related changes in left and right ventricular geometries and functions. Echocardiography of a healthy subject group. Circ J. 2011;75(12):2840-6.

14. Swift AJ, Capener D, Hammerton C, Thomas SM, Elliot C, Condliffe R, Wild $J M$, Kiely DG. Right ventricular sex differences in patients with idiopathic pulmonary arterial hypertension characterised by magnetic resonance 
imaging: pair-matched case controlled study. PLoS One. 2015;10(5): e0127415. doi:10.1371/journal.pone.0127415.

15. de Souza E, Silva CG, Franklin BA, Forman DE, Araújo CG. Influence of age in estimating maximal oxygen uptake. J Geriatr Cardiol. 2016;13(2):126-31. doi:10.11909/j.issn.1671-5411.2016.02.010.

16. Hayashi S, Yamada H, Nishio S, Hotchi J, Bando M, Takagawa Y, Saijo Y, Hirata Y, Sata M. Age- and gender-specific changes of tricuspid annular motion velocities in normal hearts. J Cardiol. 2015;65(5):397-402. doi:10.1016/j.jjcc.2014.06.013

17. Kane GC, Sachdev A, Villarraga HR, Ammash NM, JK O, McGoon MD, Pellikka PA, McCully RB. Impact of age on pulmonary artery systolic pressures at rest and with exercise. Echo Res Pract. 2016;3(2):53-61. doi:10.1530/ERP-16-0006.

18. Delcroix M, Mélot C, Vachiéry $\mathrm{L}$, Lejeune $\mathrm{P}$, Leeman $\mathrm{M}$, Vanderhoeft $\mathrm{P}$, Naeije R. Effects of embolus size on hemodynamics and gas exchange in canine embolic pulmonary hypertension. J Appl Physiol. 1990;69(6):2254-61.

19. Tuder RM, Abman SH, Braun T, Capron F, Stevens T, Thistlethwaite PA, Haworth SG. Development and pathology of pulmonary hypertension. J Am Coll Cardiol. 2009;54(Suppl 1):3-9.

Submit your next manuscript to BioMed Central and we will help you at every step:

- We accept pre-submission inquiries

- Our selector tool helps you to find the most relevant journal

- We provide round the clock customer support

- Convenient online submission

- Thorough peer review

- Inclusion in PubMed and all major indexing services

- Maximum visibility for your research

Submit your manuscript at www.biomedcentral.com/submit
Biomed Central 